\title{
Produksi Bioetanol Dari Limbah Kulit Kopi Menggunakan Enzim \\ Zymomonas Mobilis Dan Saccharomyces Cereviseae
}

\author{
Saisa $^{1 *}$, Maliya Syabriana ${ }^{2}$ \\ 1,2 Program Studi Teknik Kimia, Fakultas Teknik, Universitas Serambi Mekkah \\ Jln. Tgk Imum Lueng Bata, Banda Aceh 23245 \\ *Koresponden email: saisa@serambimekkah.ac.id
}

Diterima: 15 Desember 2017

Disetujui: 18 Desember 2017

\begin{abstract}
The availability of coffee leather waste is quite large in Aceh, because coffee processing will produce $65 \%$ coffee beans and $35 \%$ of coffee leather waste, while coffee production in Central Aceh in 2013 reaches a total of 26 thousand tons. Coffee skin waste has fiber content of $65.2 \%$. The purpose of this study is expected to create a new source of renewable energy that is environmentally friendly and can overcome the scarcity of fuel. The process of making bioethanol is done by hydrolyzing the waste of coffee skin into glucose using $\mathrm{HCl}$ catalyst. Furthermore, glucose is fermented into bioethanol using Saccharomyces cereviseae and Zymomonas Mobilis bacteria. The variables performed were fermentation time of 5, 7 and 9 days, starter concentration 5\%,10\% and $15 \%$ and ratio of enzyme combination of Saccharomyces cereviseae and Zymomonas mobilis (1: 2, 1: 1, 2: 1). This study is expected to find the best yield and ethanol content when compared with no enzyme combination.
\end{abstract}

Keywords: Bioethanol, Hydrolysis, Fermentation, Waste of coffee skin, enzyme

Abstrak.Ketersediaan limbah kulit kopi cukup besar di Aceh, karena pada pengolahan kopi akan menghasilkan 65\% biji kopi dan 35\% limbah kulit kopi, sedangkan produksi kopi di Aceh Tengah pada tahun 2013 mencapai total 26 ribu ton. Limbah kulit kopi mempunyai kandungan serat sebesar 65,2\%. Tujuan penelitian ini diharapkan terciptanya sumber energi baru terbarukan yang ramah lingkungan dan dapat mengatasi kelangkaan BBM. Proses pembuatan bioetanol dilakukan dengan menghidrolisis limbah kulit kopi menjadi glukosa menggunakan katalis $\mathrm{HCl}$. Selanjutnya glukosa difermentasikan menjadi bioetanol menggunakan bakteri Saccharomyces cereviseae dan Zymomonas Mobilis. Variabel yang dilakukan adalah waktu fermentasi 5, 7 dan 9 hari, konsentrasi starter 5\%, 10\% dan 15\% dan rasio kombinasi enzim Saccharomyces cereviseae dan Zymomonas mobilis (1:2, 1:1, 2:1). Penelitian ini diharapkan dapat menemukan kondisi yield dan kadar etanol terbaik jika dibandingkan dengan tanpa kombinasi enzim.

Kata kunci: Bioetanol, Hidrolisis, Fermentasi, Limbah kulit kopi, enzim

\section{Pendahuluan}

Biomassa merupakan sumber energi terbarukan yang saat sekarang ini sedang memperoleh perhatian tinggi. Faktor lingkungan, alasan politik, dan keamanan yang mampu mengurangi ketergantungan pada minyak mentah impor, memiliki peranan penting dalam proses pemanfaatan sumber daya terbarukan ini. Salah satu contoh bahan yang dapat digunakan untuk memproduksi bioetanol adalah limbah kulit kopi jenis robusta dan arabika yang banyak terdapat di daerah Aceh Tengah dan sekitarnya.Salah satu sentra produksi kopi nasional yang cukup terkenal dengan kopi specialty-nya adalah Kabupaten Aceh Tengah yang terletak di Provinsi Aceh. Kopi asal Kabupaten Aceh Tengah terkenal dengan Kopi Gayo yang sudah mendapatkan sertifikasi Indikasi Geografis (Mawardo, dkk., 2013).

Bioetanol memiliki kelebihan dibanding dengan BBM, diantaranya memiliki kandungan oksigen yang lebih tinggi (35\%) sehingga terbakar lebih sempurna, benilai oktan lebih tinggi (118) dan lebih 


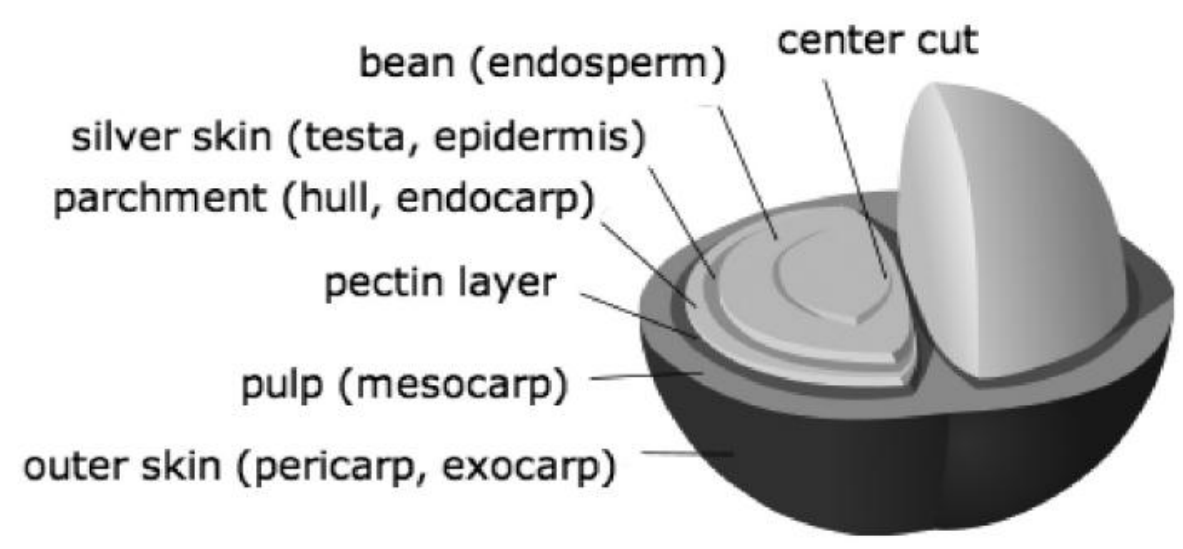

Gambar 1. Struktur Kopi (Otieno, 2009)

ramah lingkungan karena mengandung emsisi gas CO lebih rendah 19-25\% (Indartono, 2005). Selain itu bioetanol dapat diproduksi oleh mikroorganisme secara terus menerus. Produksi bioetanol di berbagai Negara telah dilakukan dengan menggunakan bahan baku yang berasal dari hasil pertanian dan perkebunan (Sarjoko, 1991).

Berbagai upaya telah dilakukan dalam mencari bahan bakar alternatif lain dari sektor non pangan untuk pembuatan bioetanol. Bahan selulosa memiliki potensi sebagai bahan bakar alternatif pembuatan etanol. Salah satu contohnya adalah limbah kulit kopi. Ketersediaan limbah kulit kopi cukup besar di Aceh, karena pada pengolahan kopi akan menghasilkan $65 \%$ biji kopi dan 35\% limbah kulit kopi, sedangkan produksi kopi di Aceh Tengah pada tahun 2013 mencapai total 26 ribu ton. Limbah kulit kopi mempunyai kandungan serat sebesar 65,2\% (Melyani, 2009).

Berlatar belakang produksi kopi di Kabupaten Aceh Tengah yang sangat besar tersebut maka pengelolaan limbah menjadi hal yang sangat penting untuk dijadikan kebijakan bagi perkebunan kopi pada umumnya dan kopi rakyat pada khususnya agar dalam pengolahan kopi dapat memproduksi kopi yang melimpah dengan tetap memperhatikan keseimbangan dan kesehatan lingkungan melalui pemanfaatan bahan baku limbah seperti limbah kulit kopi menjadi bahan yang sangat bermanfaat. Diharapkan dengan penelitian ini dapat dihasilkan solusi untuk bioetanol sebagai sumber energi terbarukan, murah dan ramah lingkungan (go green).

\section{Tinjauan Pustaka}

\subsection{Prospek Limbah Kulit Kopi \\ 2.1.1 Buah Kopi}

Buah kopi dibedakan menjadi beberapa jenis tergantungspesiestanamanyangmenghasilkannya. Kopi yang banyak dikembangkan di Indonesia meliputi kopi robusta (Coffea canephora) dan arabika (Coffea arabica). Diantara kedua jenis kopi ini, kopi robusta lebih banyak dikembangkan karena tahan terhadap penyakit karat kopi, buah yang dihasilkan lebih tinggi, dan juga lebih adaptif sehingga bisa ditanam di dataran rendah. Buah kopi memiliki beberapa bagian yang bisa terlihat jika dilakukan pemotongan secara membujur. Bagian-bagian buah kopi bisa dilihat pada Gambar 1. Bagian utama dalam buah kopi adalah kulit luar buah yang berwarna merah saat masak (epikarp), lapisan lendir buah (mesokarp), cangkang kopi (endokarp), dan embrio kopi. Epikarp dan mesokarp kopi memiliki kandungan

Tabel 1. Kandungan zat makanan kulit buah kopi berdasarkan metode pengolahan

\begin{tabular}{ccccccc}
\hline \multirow{2}{*}{$\begin{array}{c}\text { Metode } \\
\text { Pengolahan }\end{array}$} & BK $(\%)$ & \multicolumn{5}{c}{$\%$ Bahan Kering } \\
\cline { 3 - 7 } & & PK & SK & Abu & LK & BETN \\
\hline Basah & 23 & 12.8 & 24.1 & 9.5 & 2.8 & 50.8 \\
Kering & 90 & 9.7 & 32.6 & 7.3 & 1.8 & 48.6 \\
\hline
\end{tabular}

Sumber: Murni, dkk (2008) 
air yang cukup tinggi, sehingga memiliki tekstur kulit yang lunak. Endokarp buah berupa cangkang berwarna putih dan keras.

Kopi termasuk tanaman yang menghasilkan limbah hasil sampingan yang cukup besar dari hasil pengolahan. Biji kopi secara berurutan terlindungi oleh kulit buah (Outer skin), daging buah (mesocarp), lapisan lender, kulit tanduk (pactin layer) dan kulit ari (parchment). Pengupasan kulit buah kopi (pulping) merupakan salah satu tahapan proses pengolahan kopi yang membedakan antara pengolahan kopi cara basah dengan kering. Mesin pengupasan kulit kopi basah (pulper) digunakan untuk atau komponen kulit buah dari bagian kopi berkulit cangkang (Widyotomo, 2012).

\subsubsection{Limbah Kopi}

Potensi limbah yang diperoleh dari tahapan pengolahan kopi adalah kulit kopi yang terdiri atas kulit buah basah, limbah cair yang mengadung lendir, dan kulit gelondong kering maupun cangkang kering. Limbah sampingan berupa kulit kopi jumlahnya berkisar antara 50 - 60 persen dari hasil panen. Bila hasil panen sebanyak 1000 kg kopi segar berkulit, maka yang menjadi biji kopi sekitar 400-500 kg dan sisanya adalah hasil sampingan berupa kulit kopi (Efendi dan Harta, 2014).

Kulit gelondong kering yang terdiri dari kulit luar dan kulit buah mengandung gula reduksi, gula non pereduksi dan senyawa pektat masingmasing sebesar $12,4 \% ; 2,02 \%$ dan $6,52 \%$ (Wilbaux, 1963 dalam Widyotomo, 2012) dan $10,7 \%$ protein kasar serta $20,8 \%$ serat kasar (Elias, 1979 dalam Widyotomo, 2012).Limbah kulit kopi mempunyai kandungan serat sebesar 65,2 \%. (Siswati, dkk., 2012). Dengan proses fermentasi, mikroorganisme akan mengubah glukosa setelah proses hidrolisis menjadi etanol. Delapan puluh dua persen luasan area perkebunan kopi di Indonesia didominasi oleh kopi jenis Robusta, sedangkan sisanya sebesar $18 \%$ berupa kopi Arabika (Widyotomo, 2012).

Kulit buah kopi merupakan limbah dari pengolahan buah kopi untuk mendapatkan biji kopi yang selanjutnya digiling menjadi bubuk kopi. Kandungan zat makanan kulit buah kopi dipengaruhi oleh metode pengolahannya apakah secara basah atau kering seperti terlihat pada Tabel 1. Kandungan zat makanan kulit buah kopi berdasarkan metode pengolahan. Pada metode pengolahan basah, buah kopi ditempatkan pada tanki mesin pengupas lalu disiram dengan air, mesin pengupas bekerja memisahkan biji dari kulit buah. Sedangkan pengolahan kering lebih sederhana, biasanya buah kopi dibiarkan mongering pada batangnya sebelum dipanen. Selanjutnya langsung dipisahkan biji dan kulit buah kopi dengan menggunakan mesin. Ketersediaan Bahan Baku

Pemanfaatan limbah sebagai bahan bioetanol merupakan alternatif dalam meningkatkan ketersediaan bahan bakar minyak di Indonesia. Limbah mempunyai proporsi pemanfaatan yang besar dalam penghasil bahan bakar minyak penganti BBM. Bahan bakar konvensional yang sering digunakan dalam produksi bahan bakar minyak sebagian besar berasal dari limbah dan pencarian bahan yang belum lazim digunakan.

Menurut data statistik (BPS, 2013), produksi biji kopi di Indonesia mencapai 611.100 ton dan menghasilkan kulit kopi sebesar 1.000.000 ton. Jika tidak dimanfaatkan akan menimbulkan pencemaraan yang serius. Pengolahan cara kimia dengan amoniak $\left(\mathrm{NH}_{3}\right)$ disebut sebagai amoniasi. Keuntungan pengolahan ini, selain meningkatkan daya cerna juga sekaligus meningkatkan kadar protein, dapat menghilangkan aflatoksin dan pelaksanaannya sangat mudah. Kelemahannya pengolahan ini utamanya untuk pakan ruminansia. Amoniak dapat menyebabkan perubahan komposisi dan struktur dinding sel sehingga membebaskan ikatan antara lignin dengan selulosa dan hemiselulosa dan memudahkan pencernaan oleh selulase mikroorganisme. Amoniak akan terserap dan berikatan dengan gugus asetil dari bahan pakan, kemudian membentuk garam amonium asetat yang pada akhirnya terhitung sebagai protein bahan. Struktur dinding sel kulit kopi menjadi lebih amorf dan tidak berdebu, sehingga menjadi lebih mudah di tangani.

Kulit kopi mempunyai kandungan $\mathrm{BK}=90.52$, $\mathrm{PK}=6.27, \mathrm{LK}=1.31, \mathrm{SK}=34.11 \mathrm{dan} \mathrm{TDN}=57.20 \%$. Namun demikian kulit kopi hanya sebagian kecil dimanfaatkan sebagai penghasil bahan bakar minyak (bioetanol) dan sebagian besar lainnya dibuang atau dibenamkan dalam tanah untuk 
Tabel 2.2 Komposisi kandungan limbah kulit kopi

\begin{tabular}{|c|c|c|}
\hline Zat Nutrisi & $\begin{array}{ll}\text { Kandungan(\%) } & \text { Tanpa } \\
\text { diamonisasi } & \\
\end{array}$ & $\begin{array}{c}\text { Kandungan (\%) } \\
\text { Setelah iamonisasi }\end{array}$ \\
\hline Bahan Kering (BK) & 90.52 & 94.85 \\
\hline Lemak Kasar (LK) & 1.31 & 1.93 \\
\hline Serat Kasar (SK) & 34.11 & 27.52 \\
\hline Protein Kasar (PK) & 6.27 & 8.67 \\
\hline $\mathrm{Abu}$ & 7.54 & 8.47 \\
\hline Kadar Air & 9.48 & 5.15 \\
\hline
\end{tabular}

Hasil Analisa Laboratorium Ilmu Makanan Ternak Departemen Peternakan FP USU (2010)

digunakan sebagai pupuk organik pada lahan perkebunan. Komposisi kandungan kulit kopi dijelaskan dalam Tabel 2.

\subsubsection{Prospek Ekonomis}

Pemanfaatan limbah pertanian khususnya limbah kulit kopi sebagai bahan baku alternatifproduksi bioetanol merupakan suatu alternatif dalam meningkatkan kesejahteraan masyarakat dan sangat berdampak ekomomis. Tanaman kopi adalah salah satu komoditi pertanian yang mempunyai nilai ekonomis yang tinggi. Pada pengolahan kopi dihasilkan limbah berupa kulit buah kopi yang di manfaatkan petani sebagai pupuk, pakan ternak dan bahan baku produksi bioetanol (Zainuddin dan Murtisari 1995). Dalam kondisi segar buah kopi terdiri dari kulit buah $45 \%$, mucilage $10 \%$, kulit biji $5 \%$ dan biji kopi 40\% (Murni, dkk., 2008). Berdasarkan asumsi Murni, dkk., (2008) berarti 60\% dari buah kopi adalah limbah. Total limbah kopi yang dihasilkan pada tahu 2010 mencapai 20.473 ton. Pemanfaatan limbah kopi ini antara lain dapat digunakan sebagai pakan ternak dan sebagai bahan baku produksi bioetanol dalam upaya meningkatkan kesehatan lingkungan. Mustika, dkk., (2014) mengungkapkan bahwa salah satu alternatif untuk penyediaan pakan yang murah dan kompetitif dapat melalui pemanfaatan limbah baik hasil pertanian maupun industri.Hasil analisis dilaboratorium Teknologi Industri Pakan Fakultas Peternakan Universitas Andalas, kulit buah kopi mengandung protein kasar $10.78 \%$ dan serat kasar 33.13\%. Disamping itu kulit buah kopi mengandung lignin $24.67 \%$ dan selulosa $20.22 \%$ (Nuraini, ddk., 2015).

\subsection{Produksi Bioetanol}

Bioetanol dapat dibuat dari berbagai bahanhasil pertanian, antara lain bahan yang mengandungturunan gula (sakarin), bahan yang mengandungpati dan bahan yang mengandung selulosa sepertikayu, dan beberapa limbah pertanian lainnya. Bahan yang mengandung sakarin dapat langsung difermentasi, akan tetapi bahan yang mengandung pati dan selulosa harus dihidrolisis terlebih dahulu menjadi komponen yang sederhana, meskipun pada dasarnya fermentasi dapat langsung menggunakan enzim tetapi saat ini industri fermentasi masih memanfaatkan mikroorganisme karena cara ini jauh lebih mudah dan murah, mikroba yang banyak digunakan dalam proses fermentasi adalah khamir, kapang dan bakteri (Krisno dan Budyanto, 2002).

Hidrolisis yang paling sering digunakan untuk menghidrolisis selulosa adalah hidrolisis secara asam. Beberapa asam yang umum digunakan untuk hidrolisis asam antara lain adalah asam sulfat $\left(\mathrm{H}_{2} \mathrm{SO}_{4}\right)$, asam perklorat, dan $\mathrm{HCl}$. Hidrolisis asam dapat dikelompokkan menjadi hidrolisis asam pekat dan hidrolisis asam encer (Taherzadeh dan Karimi, 2007).

Penggunaan asam pekat pada proses hidrolisis selulosa dilakukan pada temperatur yang lebih rendah daripada asam encer. Konsentrasi asam yang digunakan adalah 10-30\% (Zimbardi, 1997). Temperatur reaksi adalah $100{ }^{\circ} \mathrm{C}$ dan membutuhkan waktu reaksi antara 2-6 jam. Temperatur yang lebih rendah meminimalisasi degradasi gula. Keuntungan dari penggunaan asam pekat ini adalah konversi gula yang dihasilkan tinggi, yaitu bisa mencapai konversi 90\% (Badger, 2002), kemudian glukosa difermentasi 
dengan menggunakan bakteri atau ragi yang dapatmengkonversi gula menjadi bioetanol.

Proses fermentasi gula hasil hidrolisis kulit kopi menjadi bioethanol menggunakan bakteri Zymomonasmobilis adalah bakteri yang berbentukbatang, termasuk dalam bakteri gram negatif, tidakmembentuk spora, dan merupakan bakteri yangdapat bergerak (Lee, dkk., 1979).

Bakteri ini banyak digunakan di perusahaan bioetanol karena mempunyai kemampuan yang dapat melampaui ragi dalam beberapa aspek. Zymomonas Mobilis memiliki beberapa kelebihan dibandingkan dengan Sacharomyces Cerevisieae yaitu: dapat tumbuh secara anaerob fakultatif dan mempunyai toleransi suhu yang tinggi, mempunyai kemampuan untuk mencapai konversi yang lebih tinggi, tahan terhadap kadar etanol yang tinggi dan $\mathrm{pH}$ yang rendah, mampu menghasilkan yield etanol $92 \%$ darinilai teoritisnya. Suhu optimum proses fermentasi dengan menggunakan Zymomonas mobilis adalah pada kisaran $\mathrm{pH}$ 4-7. Bioetanol hasil fermentasi dapat dimurnikan lagi dengan proses destilasi pada suhu $80^{\circ} \mathrm{C}$ sesuai dengan kadar yang diinginkan (Gunasekaran dan Raj, 1999).

\section{Metode Penelitian}

Tahapan penelitian yang akan dilakukan dalam penelitian ini dimulai dari studi literarur, pengambilan bahan baku limbah kulit kopi yang di datangkan dari Kabupaten Aceh Tengah, persiapan bahan baku mulai dari preparasi bahan sampai ketahap proses, tahapan proses terdiri dari proses hidrolisis, proses fermentasi dan proses destilasi, serta tahapan akhir yaitu analisa bahan baku dan analisa produk.

\subsection{Alat dan Bahan}

Adapun alat yang digunakan dalam penelitian ini diantaranya yaitu: Blender, Ayakan 100 mesh, Oven shimadzu, Heating matel, satu set Alat hidrolisis, satu set alat Destilasi sederhana, Neraca analitik, Thermometer $200{ }^{\circ} \mathrm{C}$, kompor listrik, $\mathrm{pH}$ meter, botol fermetasi, $\mathrm{pH}$ Universal, dan alat-alat gelas lainnya.

Bahan yang digunakan dalam penelitian ini yaitu: Asam klorida, Natrium hidroksida, Asam sulfat, glukosa, Urea, Ezim Saccharomyces cereviseae dan Zymomonas mobilis.

\subsection{Variabel Penelitian}

Variabel penelitian dibagi menjadi dua bagian yaitu variabel tetap dan variabel berubah. Adapun yang menjadi variabel tetap terdiri dari berat limbah kulit kopi sebesar 500 gram dan ukuran ayakan 100 mesh. Sedangkan yang menjadi variabel berubah yaitu konsentrasi starter (5 $\% \mathrm{v} / \mathrm{v}, 10 \% \mathrm{v} / \mathrm{v}$ dan $15 \% \mathrm{v} / \mathrm{v})$, rasio kombinasi enzim saccharomyces cereviseae dan zymomonas mobilis (1:2, 1:1 dan 2:1) dan waktu fermentasi (5 hari, 7 hari dan 9 hari).

\subsection{Prosedur Penelitian \\ 3.3.1 Persiapan Bahan Baku}

Limbah kulit kopi dibersihkan terlebih dahulu kemudian dikeringkan dengan menggunakan oven pada suhu $100{ }^{\circ} \mathrm{C}$ selama 2 jam, kemudian kulit kopi dihancurkan dengan menggunakan blender sehingga diperoleh hasil berbentuk serbuk, serbuk kulit kopi kemudian diayak menggunakan ayakan dengan ukuran 100 mesh dan dilakukan analisa kandungan sellulosa pada bahan dengan menggunakan alat spektrofotometer.

\subsubsection{Proses Hidrolisis}

Bahan serbuk kopi ditimbang sebanyak 100 gram, diambahkan aquadest dan katalis asam $\mathrm{HCl}$ dengan perbandingan volume $20 \% \mathrm{v} / \mathrm{v}$ hingga total larutan 1 liter, kemudian dimasukkan kedalam labu hidrolisis dan hidrolisis dengan suhu $100^{\circ} \mathrm{C}$ selama 4 jam, dan disaring larutan hasil hidrolisis dan ambil filtrat untuk dianalisis kadar glukosanya dengan spektrofotometer.

\subsubsection{Proses Fermentasi}

Pengambilan filtrat dari proses hidrolisis sebanyak $500 \mathrm{ml}$ dan tambahkan $\mathrm{NaOH} 1 \mathrm{~N}$ hingga $\mathrm{pH}=6$, Sampel kemudian disterilkan dalam autoklaf pada suhu $120^{\circ} \mathrm{C}$ selama 15 menit. Dinginkan hingga suhu ruang, dan dimasukkan starter (Saccharomyces cereviseae dan Zymomonas mobilis) dengan volume starter 5, 10 dan $15 \%$ (v/v) dan dikocok, lakukan juga untuk kombinasi perbandingan rasio enzim. Fermentasi larutan dengan cara memasukkan larutan ke dalam botol yang ditutup hingga rapat dan dihubungkan dengan selang gas yang dialirkan kedalam botol lain yang berisi air, fermentasi sesuai dengan variabel waktu fermentasi yaitu 5, 7 dan 9 hari 


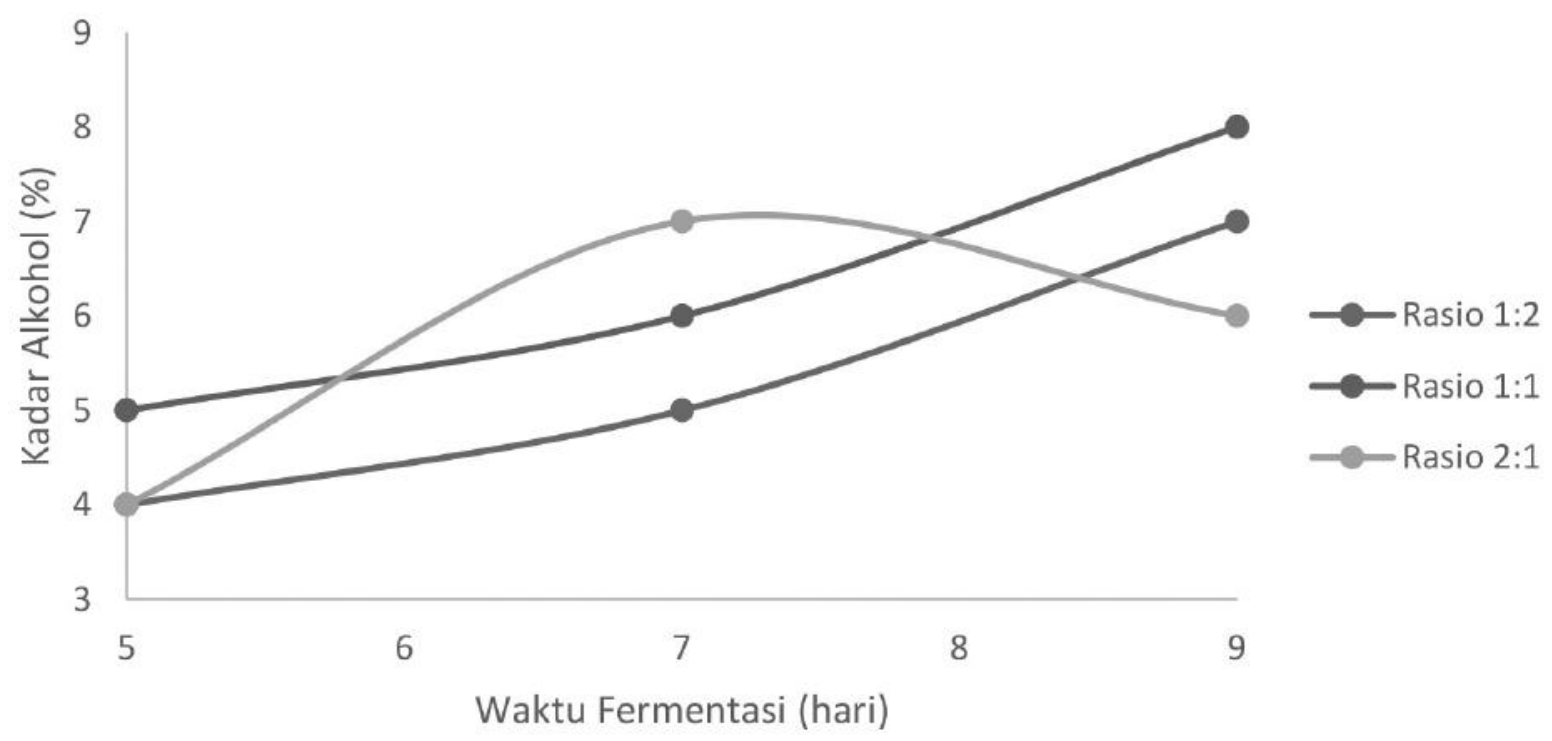

Gambar 2. Yield kadar alhokol pada variasi rasio

dengan suhu fermentasi $30^{\circ} \mathrm{C}$, dan disaring dan ambil filtrat untuk proses destilasi.

\subsubsection{Proses Destilasi}

Pengambilan filtrat hasil fermentasi kemudian dilakukan pemisahan berdasarkan titik didih yaitu destilasi yang dilakukan pada suhu $80^{\circ}$, hasil destilasi kemudian dilakukan pengukuran kadar alkoholnya.

\subsubsection{Analisa Bahan baku dan Produk}

Analisa bahan baku dilakukan dengan menggunakan alat spektrofotometri sedangkan produk yang berupa glukosa/gula pereduksi di analisa dengan menggunakan metode spektrofotometri, untuk rendemen produk dan hasil destilasi dilakukan dengan mengukur kadar alkohol dengan menggunakan alkohol meter dan alat instrument GC-MS.

\section{Hasil dan Pembahasan}

Hasil penelitian dari variabel proses yang telah dilakukan diperoleh nilai kadar alkohol tertinggi seperti ditampilkan dalam Gambar 2.

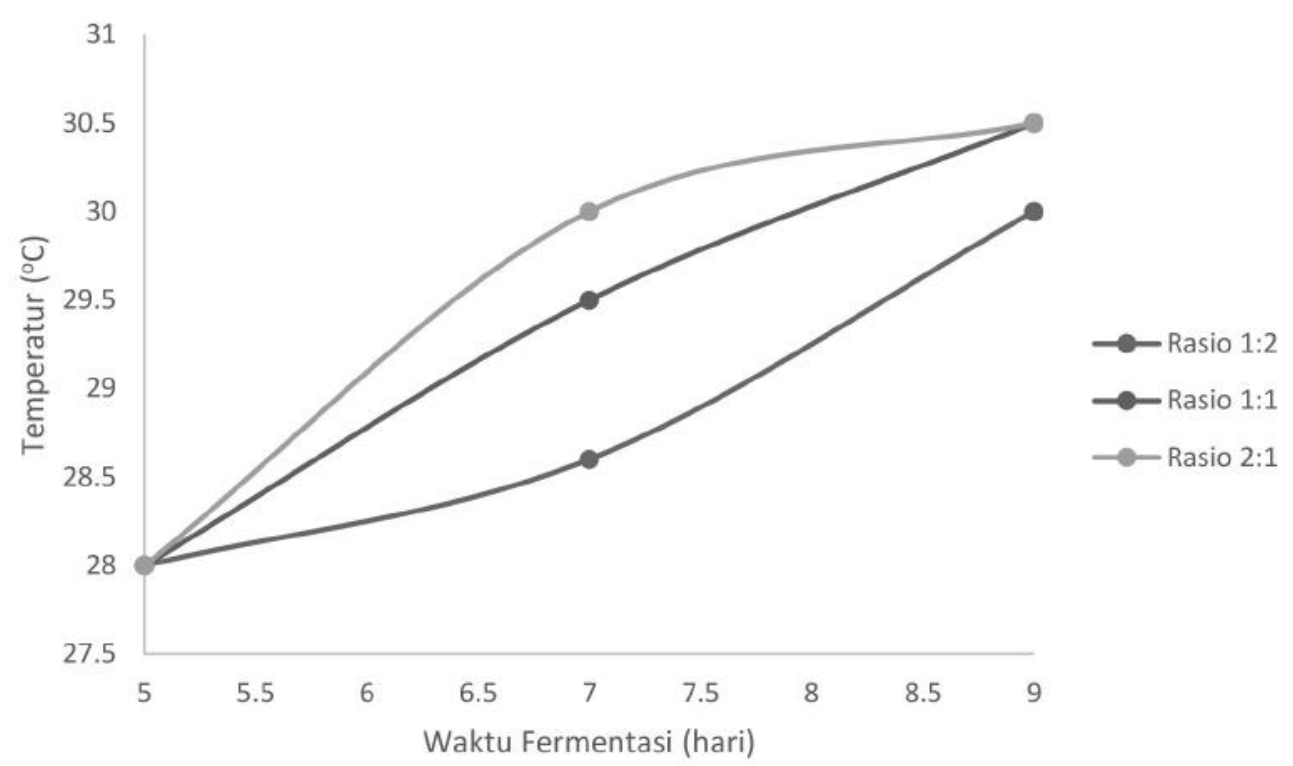

Gambar 2. Pengaruh waktu terhadap waktu fermentasi pada berbagai variasi rasio enzim 
Pada konsentrasi enzim 1:2 temperatur maksimal mencapai $30{ }^{\circ} \mathrm{C}$, pada konsentrasi 1:1 temperatur maksimal mencapai $30.5{ }^{\circ} \mathrm{C}$ dan pada konsentrasi 2:1 temperatur maksimal mencapai $30.5^{\circ} \mathrm{C}$, sehingga temperatur sangat berpengaruh selama proses fermentasi berlangsung. Laju fermentasi mikroba sangat sensitif terhadap perubahan $\mathrm{pH}$. Nilai $\mathrm{pH}$ yang sesuai di dalam proses fermentasi etanol adalah 4,0 sampai 6,0. Pada tiap konsentrasi enzim dapat dilihat bahwa terjadi kenaikan temperatur untuk masing-masing waktu fermentasi ( 5 hari, 7 hari, dan 9 hari). Hal ini disebabkan karena pada setiap waktu fermentasi dari masing-masing konsentrasi enzim, mengalami kenaikan nilai alkohol, yang berkisar antara $4 \%$ sampai dengan $8 \%$ pada rasio enzim yaitu 1:1.

Temperatur fermentasi yang dihasilkan sudah mencapai angka maksimal untuk sebagian proses fermentasi, tetapi tidak bertahan dalam waktu yang lama sehingga hanya dapat mengahasilkan etanol dalam jumlah yang mendaki maksimum yaitu $9,04 \%$ (Siswati, dkk., 2012). Ketika proses fermentasi berlangsung, temperatur maksimum tercapai $30,5{ }^{\circ} \mathrm{C}$ sedangkan temperatur minimum $28{ }^{\circ} \mathrm{C}$ untuk masing-masing subtrat. Temparatur maksimum diperoleh pada dua kondisi rasio enzim yang digunakan yaitu pada kombinasi rasio enzim 1:1 dan pada rasio enzim 2:1.

Manfaat dari hasil penelitian ini dimana produk bioethanol yang dihasilkan dapat digunakan sebagai bahan bakar alternatif pengganti BBM, sehingga mampu mengatasi kelangkaan energi bahan bakar. Kelangkaan energi yang selama ini terjadi sudah menjadi tatanan pemikiran bagi masyarakat untuk mampu mengolah limbah menjadi sumber energi baru yaitu bioetanol, Kesederhanaan proses yang mampu dilakukan oleh berbagai elemen masyarakat sehingga menjadi kegiatan rutin setelah selesai memproduksi biji kopi.

\section{Kesimpulan}

Dari hasil penelitian yang telah dilakukan dengan kondisi proses yang telah diaplikasikan pada penelitian dapat diambil beberapa kesimpulan sebagai berikut:

1. Penggunaan kedua medium fermentasi yaitu saccharomyces cerevisiae dan zimomonas mobilis pada proses pembentukan entanol mampu menghasilkan hasil yang optimum,

2. Kedua mikroba yang digunakan, baik itu saccharomyces cerevisiae dan zomomonas mobilis memiliki kemampuan baik dalam menghasilkan etanol yaitu sebesar $8 \%$ volume/volume, dan

3. Variasi temperature dan derajat keasaman $(\mathrm{pH})$ dapat meningkat seiring dengan meningkatnya jumlah etanol dan kondisi tersebut terhenti disaat proses ferentasi dihentikan.

\section{Luaran Penelitian}

Pelaksanaan penelitian ini menghasilkan luaran yang berupa produk bioethanol yang diperoleh dari hasil fermentasi limbah kulit kopi dengan kandungan gula pereduksi menggunakan saccharomyces cerevisiae dan zimomonas mobilis, sedangkan luaran lain berupa artikel ilmiah yang telah dilaksanakan pada seminar nasional.

\section{Ucapan Terima Kasih}

Penulis mengucapkan terima kasih kepada Direktorat Riset dan Pengabdian Masyarakat (DRPM), Kementerian Riset, Teknologi dan Pendidikan Tinggi yang telah memberikan bantuan dana Hibah Penelitian Dosen Pemula (PDP) selanjutnya ucapan terima kasih kepada Universitas Syiah Kuala dan Universitas Serambi Mekkah Banda Aceh yang telah memberikan dukungan dan fasilitas sehingga tercapainya target penelitian ini.

\section{Daftar Pustaka}

Badan Pusat Statistik. 2013. Aceh Tengah Dalam Angka 2013. Direktorat Pengembangan Potensi Daerah, Kabupaten Aceh tengah.

Badger, P. C., 2002. Ethanol from Cellulose : A General Review. In Trend in New Cropsand New Uses., J.Jannick and A.Whipkey(eds). Alexandria,VA : ASHS Press.

Departemen Peternakan, 2010. Komposisi kandungan kulit kopi. Laboratorium Ilmu Makanan Ternak Departemen Peternakan FP USU.

Efendi, Z., dan Harta, L., 2014. Kandungan Nutrisi Hasil Fermentasi Kulit Kopi (Studi Kasus Desa Air Meles Bawah Kecamatan Curup Timur. Jurnal BPTP Bengkulu, Bengkulu. 
Gunasekaran, P. and Raj, K. C. 1999.Ethanol Fermentation Technology -Zymomonas mobilis.Current Science. Vol. 77, \#1, 56-68 diambil dariGhani Arasyid dkk.

Indartono, Y., 2005. Bioethanol, Alternatif Energi Terbarukan: Kajian Prestasi Mesin dan Implementasi di Lapangan. Fisika, LIPI.

Krisno, A dan Budyanto, Moch., 2002. mikrobiologi terapan. Malang: Universitas Muhammadiah Malang.

Lee, K.J., Tribe, D.E. and Rogers, P.L., 1979. Biotechnol. Lee, K.J., Suku, D.E. dan Rogers, P.L, 1979. Biotechnol.Lett., 1 , 421. Lett1.,, 421.

Mawardo, S., Retno, H., Aris, W., Soekadar, W., dan Yusianto. 2013. Panduan Budidaya dan Pengolahan Kopi Arabika Gayo. Gramedia Pustaka Utama: Jakarta.

Melyani, V.2009. Petani Kopi Indonesia Sulit Kalahkan Brazil.(http://www. tempointeraktif.com/hg/bisnis/2009/07/02/ brk,20090702-184943,id.html) diakses tanggal 27 Mei 2016.

Murni, R., Suparjo., Akmal dan Ginting, D.L., 2008. Buku Ajar Teknologi Pemanfaatan Limbah Untuk Pakan. Laboratorium Makanan Ternak Fakultas Peternakan Universitas Jambi.

Mustika, A.I.C., O. Sjofjan., dan E. Widodo, 2014. Pengaruh Penambahan Tepung Kulit Buah Naga Merah (Hylocereus Polyrhyzus) dalam Pakan terhadap Penampilan Produksi Burung Puyuh (Coturnix Japonica). Skripsi. Universitas Brawijaya Malang.

Nuraini, Y. Marlida, Mirzah, R. Disafitri, dan R. Febrian, 2015. Peningkatan Kualitas Limbah Buah Kopi dengan Phanerochaete chrysosporium sebagai Pakan Alternatif. Jurnal Peternakan Indonesia. Volume (17), issue 2.

Otieno, 2009. Struktur Kopi. http://blog. garasco.co.id/bagian-tentang-biji-kopi/ diakses 15 september 2016.

Sarjoko. 1991. Bioteknologi Latar Belakang dan Beberapa Penerapannya. Gramedia Pustaka Umum, Jakarta.
Siswati, N. D, Yatim, M., dan Hidayanto, R. 2012. Bioetanol dari Limbah Kulit Kopi dengan Fermentasi. Jurnal Jurusan Teknik Kimia Fakultas Teknologi Industri, Universitas Pembangunan.

Taherzadeh, Mohammad J. And Keikhosro Karimi.2007. Enzyme-based Hydrolysis Processes for Ethanol from Lignocellulosic Materials : A review. Sweden : University of Boras. Department of Chemical Engineering.

Widyotomo, S. 2012. Potensi Dan Teknologi Diversifikasi Limbah Kopi Menjadi Produk Bermutu Dan Bernilai Tambah. Review Penelitian Kopi dan Kakao 1(1) 2013, hal 63-80.

Zainuddin, D. dan T. Murtisari, 1995. Penggunaan limbah agro-industri buah kopi (kulit buah kopi) dalam ransum ayam pedaging (Broiler). Pros. Pertemuan Ilmiah Komunikasi dan Penyaluran Hasil Penelitian. Semarang. Sub Balai Penelitian Ternak Klepu, Puslitbang Peternakan, Badan Litbang Pertanian. hlm. 71-78.

Zimbardi, 1997. Hidrolisis tandan kosong kelapa sawit menjadi bioethanol dengan asam pekat. Jurnal Universitas Indonesia, UI Press. 